\title{
Sensibilización de la Praxis EduTIC: en y Post Pandemia
}

PhD. Olga Carolina Molano Lucena
Red Académica Internacional de Pedagogía e Investigación, RedINDTEC
$\frac{\text { olgacmolano@gmail.com }}{\text { Florida, Estados Unidos }}$
https://orcid.org/0000-0002-0578-7346

\section{Editorial}

La realidad a nivel global ha sido trastocada por la pandemia del COVID-19, por este motivo la praxis educativa asumió configuraciones empíricas desde posiciones epistémicas resultantes de las múltiples maneras de percibir, interpretar, comprender o medir las situaciones críticas generadas en los diversos contextos formativos, para responder a las características estudiantiles de cada nivel y modalidad de los sistemas educativos existentes en Latinoamérica y el Caribe, entre otras regiones del mundo.

La necesidad de trascender las exigencias sanitarias, sociales y educativas, llevaron a reflexionar acerca de la praxis formativa más allá de los ámbitos de las aulas de clases, debido a la necesidad de un aislamiento forzado. Esta situación despertó entre otros aspectos una nueva sensibilidad cognoscitiva cuyo objeto primario es la percepción o conocimiento, tanto empírico, como epistémico, lo cual, formó parte fundamental de los procesos de investigación formal e informal de la praxis pedagógica mediada por las Tecnologías de Información y Comunicación (TIC).

En este sentido, los artículos científicos presentados en el Instituto Internacional de Investigación y Desarrollo Tecnológico Educativo (INDTEC), a través de la Revista Scientific, representan producciones intelectuales generadas por investigaciones desde diversas configuraciones epistémicas y procedimentales; en las cuales se reportan diversos abordajes del conocimiento. Al respecto, Cerón (2017): señala que este "ejercicio metacientífico se antoja como un esquema organizador que dé sentido a la 
producción de conocimiento existente y que a la vez permita tomar decisiones teórico-metodológicas al momento de pretender hacer ciencia" (pág. 89). Esta declaración, abre las posibilidades a una interconexión migratoria de saberes, sin intentar desplazar unos por otros.

Por ende, esta reflexión editorial acerca de sensibilización de la praxis Educativa mediada por las Tecnologías de Información y Comunicación (EduTIC), desde la visión de los acontecimientos formativos generados por la pandemia, no obstante, los esfuerzos sanitarios de cada país, aún sigue vigente. Sin embargo, el impacto en la enseñanza y aprendizaje virtual, ha generado cambios en la percepción de las autoridades, docentes, estudiantes, padres y representantes; lo cual hace suponer un quehacer pedagógico hibrido post pandémico.

Desde la perspectiva de una educación post pandémica, Guaman, Villareal y Cedeño (2020): indican que "[...] la educación hibrida quedara como una estrategia para aplicar en nuevo proceso educativo, donde se combine herramientas virtuales con recursos didácticos de la modalidad presencial y virtual, dejando abierto a la utilización de ambos esquemas de aprendizaje [...]" (pág. 11). De esta manera, la acción didáctica permitirá a los educandos decidir cómo, cuándo y dónde estudiar, así las clases pueden ser desarrollas en condiciones mixtas, coherentes con las demandas de la sociedad global, por lo cual se debe hacer una contextualización de los perfiles curriculares del sistema educativo de cada país.

Comenzando con una visión transcompleja, se hace evidente los requerimientos de una contextualización con una visión de globalización del conocimiento, ante la complejidad social, con un mayor grado de incertidumbre en la realidad educativa. En esa misma línea, Gutierrez-Moreno (2020): expone la necesidad de "[...] corresponder a todas estas realidades, de tal manera que no se vulnere el derecho a la educación [...]. Se trata de una situación inédita que requiere de propuestas creativas y viables" (pág. 3). Sin 
olvidar, desplegar una nueva sensibilidad cognoscitiva acorde con los requerimientos formativos de la realidad socioeducativa en y post pandemia.

Asimismo, la percepción de la realidad socioeducativa en y post pandemia, requiere desarrollar una sensibilidad cognoscitiva, la cual plantea habilidades de detectar patrones perceptivos, sociales, afectivos, motivacionales; los cuales permitan la transferencia de información que se convierta en aprendizajes significativos, y además conduzcan a transformar la enseñanza en una estrategia destinada a alcanzar la calidad educativa con la medición de las TIC.

En Consecuencia, EduTIC debe responder a los requerimientos formativos desde una enseñanza-aprendizaje, destinada a la construcción de conocimientos pertinentes para dar respuestas a la realidad socioeducativa en y post pandemia; en pro de atender las exigencias entre lo contextual-local desde las pautas globales derivadas de la innovación tecnológica, sin perder de vista la sensibilidad cognoscitiva.

En este sentido, se debe desarrollar una estrategia educativa holística que involucre un sistema cognitivo sensible capaz de articular la percepción, motivación, afectividad, entre otras, como características de un humanismo más humano; es decir, de una educación inmensa en la trilogía mente, cuerpo y espíritu; como una manifestación del todo en cada una de sus partes, para articular de modo armónico, la formación personal tomando en cuenta la socialización con los otros; sin olvidar los ambientes socialesnaturales en los que está inmerso entre lo físico de las aulas de clase, y los entornos virtuales mediados por las Tecnologías de la Información y la Comunicación (TIC).

Finalmente, se trata de abrir nuevos espacios educativos con y sin la mediación de las TIC, dentro de una sensibilización cognoscitiva de los procesos de formación de los docentes y estudiantes; usando estrategias didácticas hibridas entre lo presencial-virtual, adaptadas a las necesidades 
movilidad, asociatividad y conectividad, con el fin de encontrar respuestas coherentes para responder a los requerimientos de las situación pandémica, con una mirada de complementariedad, sinergia, integralidad, reflexividad propias de la evolución de los conocimientos en función de los acontecimientos presentes y futuros.

Palabras clave: sensibilidad; praxis; educación; tic.

Fecha de Recepción: 05-02-2021
Fecha de Aceptación: 26-03-2021
Fecha de Publicación: 05-05-2021 


\section{Awareness of the EduTIC Praxis: in and Post Pandemic}

\section{Editorial}

The global reality has been disrupted by the COVID-19 pandemic, for this reason the educational praxis assumed empirical configurations from epistemic positions resulting from the multiple ways of perceiving, interpreting, understanding or measuring the critical situations generated in the various training contexts, to respond to the student characteristics of each level and modality of the existing educational systems in Latin America and the Caribbean, among other regions of the world.

The need to transcend the health, social and educational demands, led us to reflect on the training praxis beyond the scope of the classrooms, due to the need for forced isolation. This situation aroused, among other aspects, a new cognitive sensitivity whose primary object is perception or knowledge, both empirical and epistemic, which formed a fundamental part of the formal and informal research processes of the pedagogical praxis mediated by Information Technology and Communication (ICT).

In this sense, the scientific articles presented at the International Institute for Educational Technological Research and Development (INDTEC), through Scientific Magazine, represent intellectual productions generated by research from various epistemic and procedural configurations; in which various approaches to knowledge are reported. In this regard, Cerón (2017): points out that this "meta-scientific exercise seems like an organizing scheme that gives meaning to the production of existing knowledge and that at the same time allows making theoretical-methodological decisions when trying to do science" (p. 89). This declaration opens the possibilities for a migratory interconnection of knowledge, without trying to displace one by another.

Therefore, this editorial reflection on the awareness of Educational praxis mediated by Information and Communication Technologies (EduTIC), 
from the perspective of the training events generated by the pandemic, however, the health efforts of each country, is still in force. However, the impact on virtual teaching and learning has generated changes in the perception of authorities, teachers, students, parents and representatives; which suggests a post-pandemic hybrid pedagogical task.

From the perspective of a post-pandemic education, Guaman, Villareal and Cedeño (2020): indicate that "[...] hybrid education will remain as a strategy to apply in a new educational process, where virtual tools are combined with teaching resources of the face-to-face modality and virtual, leaving open to the use of both learning schemes [...]" (p. 11). In this way, the didactic action will allow students to decide how, when and where to study, so the classes can be developed in mixed conditions, consistent with the demands of global society, for which a contextualization of the curricular profiles must be made of the educational system of each country.

Starting with a transcomplex vision, the requirements of a contextualization with a vision of globalization of knowledge become evident, in the face of social complexity, with a greater degree of uncertainty in the educational reality. Along the same lines, Gutierrez-Moreno (2020): exposes the need to "[...] correspond to all these realities, in such a way that the right to education is not violated [...]. It is an unprecedented situation that requires creative and viable proposals" (p. 3). Without forgetting, deploy a new cognitive sensitivity in accordance with the training requirements of the socio-educational reality in and after the pandemic.

Likewise, the perception of the socio-educational reality in and after the pandemic requires developing a cognitive sensitivity, which raises abilities to detect perceptual, social, affective, motivational patterns; which allow the transfer of information that becomes meaningful learning, and also lead to transform teaching into a strategy aimed at achieving educational quality with the measurement of ICT. 
Consequently, EduTIC must respond to the training requirements from a teaching-learning, aimed at the construction of relevant knowledge to respond to the socio-educational reality in and post-pandemic; in favor of meeting the demands between the contextual-local from the global guidelines derived from technological innovation, without losing sight of cognitive sensitivity.

In this sense, a holistic educational strategy must be developed that involves a sensitive cognitive system capable of articulating perception, motivation, affectivity, among others, as characteristics of a more humane humanism; that is to say, of an immense education in the mind, body and spirit trilogy; as a manifestation of the whole in each of its parts, to harmoniously articulate personal formation taking into account socialization with others; without forgetting the social-natural environments in which it is immersed between the physical of the classrooms, and the virtual environments mediated by Information and Communication Technologies (ICT).

Finally, it is about opening new educational spaces with and without the mediation of ICT, within a cognitive awareness of the training processes of teachers and students; using hybrid teaching strategies between face-to-facevirtual, adapted to mobility, associativity and connectivity needs, in order to find coherent responses to respond to the requirements of pandemic situations, with a view of complementarity, synergy, comprehensiveness, reflexivity typical of the evolution of knowledge as a function of present and future events.

Keywords: sensitivity; praxis; education; ict.

Date Received: 05-02-2021
Date Acceptance:

26-03-2021
Date Publication:

05-05-2021 


\section{Referencias}

Cerón, A. (2017). Cuatro niveles de conocimiento en relación a la ciencia. Una propuesta taxonómica. CIENCIA ergo-sum, 24(1), 83-90, eISSN: 1405-0269. Recuperado de:

https://dialnet.unirioja.es/servlet/articulo?codigo $=5888348$

Guaman, R., Villareal, Á., \& Cedeño, E. (2020). La Educación Híbrida como alternativa frente al Covid-19 en el Ecuador. Revista de Investigación Científica TSE'DE, 3(1), 134-147, e-ISSN: 2600-5557. Recuperado de: http://tsachila.edu.ec/ojs/index.php/TSEDE/article/view/27

Gutierrez-Moreno, A. (2020). Educación en tiempos de crisis sanitaria:

Pandemia y educación. Praxis, 16(1), 1-4, e-ISSN: 2389-7856.

Recuperado de: https://dialnet.unirioja.es/ejemplar/548636 


\section{Olga Carolina Molano Lucena \\ e-mail: olgacmolano@gmail.com}

Nacida Jají, estado Mérida, Venezuela el, 15 de mayo

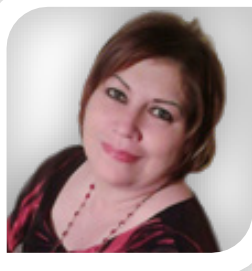
del año 1963. Licenciada en Educación por la Universidad Nacional Experimental Simón Rodríguez (UNESR); Maestría en Planificación Educativa por la Universidad Rafael Urdaneta (URU); Doctorado en Educación de la Universidad Pedagógica Experimental Libertador - Instituto Pedagógico de Barquisimeto (UPEL-IPB); Postdoctorado en Estudios Libres: La Epistemología desde su Praxis y Productividad por la Universidad Fermín Toro (UFT); Experto E-learning de la Fundación para la Actualización Tecnológica de Latinoamérica (FATLA); Docente, tutora, jurado de pregrado y postgrado; Directora de Contenido de la Red Académica Internacional de Pedagogía e Investigación (RedINDTEC), Capítulo Ecuador; Investigadora del programa de Promoción al Estímulo a la Investigación e Innovación del Ministerio de Ciencia y Tecnología (PEII- ONCTI); Adscrita al Centro de Investigación Contextos y Praxis Socio Educativa (CICPSE-UPELIPB); Diseñadora de los Proyectos socioeducativos "Cascada y LUCES"; Conferencista y escritora de artículos y libros. 